\title{
Breeding and chemical methods of brown mustard (Brassica juncea L.) protection from Fusarium blight
}

\author{
Oksana Serdyuk*, Victoria Trubina, and Lyudmila Gorlova \\ V.S. Pustovoit All-Russian Research Institute of Oil crops, 350038, 17, Filatova street, Krasnodar \\ Russian Federation
}

\begin{abstract}
The article presents the research on breeding and chemical methods of brown mustard sowings from Fusarium blight in the conditions of the central zone of the Krasnodar region. We evaluated mustard variety samples affected by the disease on a natural infectious background during the growing season. As a result, for 4 years we selected mustard breeding material resistant to Fusarium blight, which exceeds the productivity and oil content of the standard variety Yunona by $0.20-0.26 \mathrm{t} / \mathrm{ha}$ and $2.0-2.7 \%$, respectively. We tested systemic chemical fungicides from the triazoles and strobilurins groups in a chemical method study. We determined the fungicide with the active ingredients azoxystrobin $120 \mathrm{~g} / 1+$ tebuconazole $200 \mathrm{~g} / \mathrm{l}, \mathrm{SC}$ at the application rate of $1.0 \mathrm{l} / \mathrm{ha}$ which effectively decreases the spreading and development of Fusarium blight on mustard when treating plants at the stalking stage. The biological effectiveness of the preparation was $82.4 \%$, the seed yield significantly exceeded the control (by $0.36 \mathrm{t} / \mathrm{ha}$ ). Thus, it is recommended to use both breeding and chemical methods of sowings protection against the disease to effectively decrease the harmfulness of Fusarium blight on mustard.
\end{abstract}

\section{Introduction}

Brown mustard (Brassica juncea L.) belongs to the Brassicacea family of oil crops. Its seeds are used as a source of essential fatty acids. The oil is used not only for food purposes but also as a biological fuel $[1,2,7,8]$. The meal that remains after oil extraction and contains a large amount of protein is used as feed for farm animals, mustard seeds and cake are used in medicine and as a seasoning [10]. In addition, brown mustard as a green manure crop helps to improve the physical properties of the soil and its fertility $[4,5]$.

Brown mustard is not always able to realize its potential due to its affection by various diseases during the growing season. One of the common diseases is Fusarium blight in the form of tracheomycosis of plants [3]. The pathogens are fungi of the genus Fusarium spp. The pathogens infect plants through the root system. Inside the plant, they release toxins and a wide range of hydrolytic enzymes, destroying its tissues; fungal mycelium blocks

\footnotetext{
*Corresponding author: oserduk@mail.ru
} 
vascular bundles, which causes premature drying of plants, and, consequently, a decrease in yield and seed quality of brown mustard [6].

Breeding and chemical methods of plant protection are the most commonly used practices to reduce the harmfulness of Fusarium blight as well as other diseases. The breeding method involves the development of disease-resistant varieties, while the chemical method involves the use of fungicides to protect sowings against diseases. We could not find information on the use of these methods on mustard in the available literature.

The purpose of the research was to study the effectiveness of breeding and chemical methods to protect mustard from Fusarium blight in the central zone of the Krasnodar region.

\section{Methods}

We carried out the research in 2018-2021 at V.S. Pustovoit All-Russian Research Institute of Oil Crops, Krasnodar. The objects of the study were breeding samples of brown mustard in the amount of 300 pieces annually and Fusarium blight pathogens, fungi of Fusarium spp. genus causing tracheomycosis of plants.

We evaluated mustard variety samples affected by Fusarium blight against the natural infection background during the growing season, beginning from the cotyledon leaves to the stage of yellow-green pod. We used the counting data to calculate the main elements of disease statistics: prevalence and development.

We calculated the prevalence of Fusarium blight of the plants using the following formula (1):

$$
P=\frac{n}{N} 100 \%,
$$

where $\mathrm{P}-$ is the disease prevalence in a sample, $\%$;

$\mathrm{n}-$ is the number of affected plants in a sample, pcs;

$\mathrm{N}-$ is the total number of counted plants in a sample, pcs.

We divided the disease prevalence into low, medium, and high:

- low - up to $10 \%$ of plants in a sample with disease symptoms;

- medium - 11-50\% of plants in a sample with disease symptoms;

- high $-51 \%$ and more plants in a sample with disease symptoms.

We determined the intensity of Fusarium blight affection of mustard plants by a visual scale:

0 points - a healthy plant;

1 point $-1-2$ branches dry out, change color to light yellow;

2 points $-3-4$ branches dry out, change color to light yellow;

3 points - all branches dry out, change color to light yellow;

4 points - a completely dry out plant that did not form pods.

We calculated the Fusarium blight development by the following formula (2):

$$
R=\frac{\sum(a \cdot b)}{N^{*} k} 100 \%
$$

where $\mathrm{R}$ - is the disease development, \%;

$\Sigma(\mathrm{a} \times \mathrm{b})-$ is the sum of products of the number of affected plants (a) by the corresponding affection point (b);

$\mathrm{N}$ - is the total number of the counted plants (healthy and affected) in a sample;

$\mathrm{k}-$ is the highest affection point.

We divided the disease development into low, weak, average, and strong:

- low - up to $10 \%$; 
- weak - 11-30\%;

- average - 31-60\%;

- strong $-61 \%$ and higher.

We evaluated the mustard material for resistance to Fusarium blight using a visual 10point scale according to the degree of a sample affection (from 0 to 9 points), where 9 points are the maximum degree of affection.

Using this scale, we divided all breeding samples of mustard according to the degree of resistance into the following groups:

0 points - immune;

1-2 points - resistant;

3-4 points - weakly resistant;

5-6 points - weakly susceptible;

7-9 points - susceptible [9].

We carried out the fungicide test on brown mustard variety Yunona (standard variety of economically important traits) of the breeding of V.S. Pustovoit All-Russian Research Institute of Oil Crops that is common in production. We made 3 replications of the experiment with the randomized location of plots. We treated the plots with preparations at different stages of brown mustard development: 2-4 true leaves, stalking, flowering, and green pod. The application rate of the working fluid was $300 \mathrm{l} / \mathrm{ha}$. We tested systemic chemical fungicides from the groups of triazoles and strobilurins in the experiment, the active ingredients (a.i.) were:

1. tebuconazole $250 \mathrm{~g} / \mathrm{l}, \mathrm{EC}-1.0 \mathrm{l} / \mathrm{ha}$ (standard);

2. tebuconazole $250 \mathrm{~g} / \mathrm{l}+$ flutriafol $75 \mathrm{~g} / 1, \mathrm{SC}-0.9 \mathrm{l} / \mathrm{ha}$;

3. azoxystrobin $200 \mathrm{~g} / 1+$ cyproconazole $80 \mathrm{~g} / \mathrm{l}, \mathrm{SC}-1.0 \mathrm{l} / \mathrm{ha}$;

4. azoxystrobin $120 \mathrm{~g} / 1+$ tebuconazole $200 \mathrm{~g} / \mathrm{l}, \mathrm{SC}-1.0 \mathrm{l} / \mathrm{ha}$.

We calculated the biological effectiveness of fungicides using the following formula (3):

$$
\mathrm{C}=\frac{\mathrm{K}-0}{\mathrm{~K}} \cdot 100 \%,
$$

where: $\mathrm{C}-$ is the biological effectiveness of a fungicide, \%;

$\mathrm{K}-$ is the disease development in the control (without treatment), $\%$;

$\mathrm{O}-$ is the disease development in a variant after treatment, $\%$.

We divided the biological effectiveness of fungicides into high, medium, and low:

- low - up to $40,0 \%$;

- medium - 40,0-69,9\%;

- high - from $70,0 \%$ and higher.

Seeds of mustard were harvested by direct combining method. The yield was corrected to $100 \%$ of purity and $8 \%$ of moisture content.

We carried out the statistical processing of the data of independent means for yield for three years of research using Student's $t$-test. The difference between the means exists when the actual values of the $t$-test exceed the theoretical values at the significance level of $0.05 ; 0.01$ or 0.001 .

We carried out the phytoexamination of the affected parts of the mustard plants in the laboratory according to established practices. The pathogens were identified using a Motic BA300 microscope, at 400x magnification.

\section{Results}

Fungi of Fusarium spp. genus are not obligate parasites, it is impossible to develop varieties immune to Fusarium blight, i.e. mustard breeding is conducted not for vertical, but only for horizontal resistance, which, in addition to the qualities of the host plant and the pathogen 
properties, also depends on weather conditions. As a result of evaluation for resistance to Fusarium blight, we found that the prevalence and development of the disease on breeding mustard samples over the years of research ranged from low in 2019 (3.0-10.0 and 1.0$10.0 \%$ ) to high in 2018, 2020 and 2021 (4.0-55.0 and 2.0-35.0\%) (Table 1).

Table 1. Prevalence (P, \%) and development (R, \%) of Fusarium blight on the breeding samples of brown mustard, 2018-2021.

\begin{tabular}{|c|c|c|}
\hline \multirow{2}{*}{ Year } & \multicolumn{2}{|c|}{ Fusarium blight } \\
\cline { 2 - 3 } & $\mathbf{P ,} \mathbf{\%}$ & $\mathbf{R , ~ \%}$ \\
\hline 2018 & $4.0-40.0$ & $2.0-28.0$ \\
\hline 2019 & $3.0-10.0$ & $1.0-10.0$ \\
\hline 2020 & $5.0-42.0$ & $2.0-22.0$ \\
\hline 2021 & $15.0-55.0$ & $3.8-38.7$ \\
\hline
\end{tabular}

In laboratory conditions, we isolated fungi Fusarium oxysporum Schlecht., emend. Synd. et Hans, F. sporotrichiella Bilai and other species of Fusarium genus from the mustard plant parts affected by Fusarium blight. We identified fungus F. oxysporum in most variants.

The resistance degree of mustard variety samples varied according to the prevailing weather conditions. In all years of research, we did not identify mustard samples immune to Fusarium blight (Table 2).

Table 2. Resistance of brown mustard breeding samples to Fusarium blight, 2018, 2020-2021.

\begin{tabular}{|c|c|c|c|c|c|}
\hline \multirow{2}{*}{ Year } & \multicolumn{5}{|c|}{ Number of samples, \% } \\
\cline { 2 - 6 } & immune & resistant & $\begin{array}{c}\text { weakly } \\
\text { resistant }\end{array}$ & weakly susceptible & $\begin{array}{c}\text { susceptibl } \\
\text { e }\end{array}$ \\
\hline 2018 & 0 & 39 & 56 & 5 & 0 \\
\hline 2020 & 0 & 15 & 85 & 0 & 0 \\
\hline 2021 & 0 & 12 & 73 & 15 & 0 \\
\hline
\end{tabular}

The number of resistant sample varieties in the first year of the research (2018) was $39 \%$, but later there was a significant decrease, and in 2021, it amounted to $12 \%$.

The remaining samples were weakly resistant and weakly susceptible, their numbers were $55-85 \%$ and 5-15\%, respectively. In 2020, there were no samples weakly susceptible to Fusarium blight.

In addition to pathogen resistance, we studied the productivity of mustard variety samples. As a result, we found that several resistant samples (№№ 495/18, 498/18, and $506 / 18$ ) exceeded the standard variety in productivity and oil content of seeds in all years of research (Table 3).

Table 3. Prevalence (P, \%), development (R, \%) of Fusarium blight of brown mustard and characteristics of the best resistant breeding samples, 2018, 2020-2021.

\begin{tabular}{|c|c|c|c|c|c|c|}
\hline \multirow[b]{2}{*}{$\begin{array}{c}\text { Sample, } \\
\text { variety }\end{array}$} & \multirow[b]{2}{*}{$\mathbf{P}, \%$} & \multirow[b]{2}{*}{$\mathrm{R}, \%$} & \multicolumn{2}{|c|}{ Seed productivity } & \multicolumn{2}{|c|}{ Oil content of seeds } \\
\hline & & & t/ha & $\begin{array}{c} \pm \text { to } \\
\text { standard }\end{array}$ & $\%$ & \pm to standard \\
\hline $495 / 18$ & 9.0 & 6.0 & 1.58 & +0.20 & 48.2 & +2.0 \\
\hline $498 / 18$ & 10.0 & 5.5 & 1.64 & +0.26 & 48.9 & +2.7 \\
\hline $506 / 18$ & 7.5 & 4.0 & 1.62 & +0.24 & 48.7 & +2.5 \\
\hline $\begin{array}{l}\text { Yunona } \\
\text { (standard*) }\end{array}$ & 32.5 & 15.2 & 1.38 & - & 46.2 & - \\
\hline
\end{tabular}

* - standard of economically important traits. 
The productivity of these brown mustard samples exceeded the standard variety Yunona by $0.20-0.26 \mathrm{t} / \mathrm{ha}$ amounting to $1.58-1.64 \mathrm{t} / \mathrm{ha}$; oil content was increased by $2.0-2.7 \%$ amounting to $48.2-48.9 \%$.

The isolated samples will be used in the breeding process to develop new high-yielding varieties of brown mustard with high oil content and resistance to Fusarium blight.

When weather conditions are favorable for the development of disease pathogens, there can be a sharp increase in infestation of mustard sowings with Fusarium blight, so we have studied the effectiveness of chemical methods of sowings protection from the disease.

We determined that during three years of research the average prevalence of Fusarium blight on mustard at control plots (without treatment with preparations) was $45.5 \%$, the disease development $-36.3 \%$ with general intensity of plant affection of 2-3 points.

In the variants with fungicides, we observed the differences in prevalence and development of Fusarium blight, depending more on the stage of preparation application and less on the preparation itself (Table 4).

Table 4. Prevalence (P, \%), development (R, \%) of Fusarium blight of brown mustard and biological effectiveness of preparations against disease, 2018, 2020-2021.

\begin{tabular}{|c|c|c|c|c|c|c|}
\hline \multirow[b]{2}{*}{ № } & \multirow{2}{*}{$\begin{array}{c}\text { Plant } \\
\text { developme } \\
\text { nt stage }\end{array}$} & \multirow{2}{*}{$\begin{array}{c}\text { Variant } \\
\text { (a.i. of preparation) }\end{array}$} & \multirow{2}{*}{$\begin{array}{l}\text { Applicat } \\
\text { i-on } \\
\text { rate, } 1 / \mathbf{h a}\end{array}$} & \multicolumn{2}{|c|}{$\begin{array}{c}\text { Fusarium } \\
\text { blight }\end{array}$} & \multirow{2}{*}{$\begin{array}{c}\text { Biological } \\
\text { effectiveness } \\
\text { of } \\
\text { preparation, } \\
\%\end{array}$} \\
\hline & & & & $\begin{array}{l}\mathbf{P}, \\
\%\end{array}$ & $\begin{array}{l}\mathbf{R}, \\
\mathbf{\%}\end{array}$ & \\
\hline 1 & & $\begin{array}{l}\text { Control (without } \\
\text { treatment) }\end{array}$ & - & 45.5 & 36.3 & - \\
\hline 2 & \multirow{4}{*}{$\begin{array}{l}2-4 \text { of true } \\
\text { leaves }\end{array}$} & $\begin{array}{l}\text { tebuconazole } 250 \mathrm{~g} / 1, \mathrm{EC} \\
\text { (standard) }\end{array}$ & 1.0 & 34.6 & 25.2 & 30.5 \\
\hline 3 & & $\begin{array}{l}\text { tebuconazole } 225 \mathrm{~g} / 1+ \\
\text { flutriafol } 75 \mathrm{~g} / \mathrm{l}, \mathrm{SC}\end{array}$ & 0.9 & 35.5 & 26.0 & 28.4 \\
\hline 4 & & $\begin{array}{l}\text { azoxystrobin } 200 \mathrm{~g} / 1+ \\
\text { cyproconazole } 80 \mathrm{~g} / 1, \mathrm{SC}\end{array}$ & 1.0 & 34.4 & 26.4 & 27.3 \\
\hline 5 & & $\begin{array}{l}\text { azoxystrobin } 120 \mathrm{~g} / 1+ \\
\text { tebuconazole } 200 \mathrm{~g} / 1, \mathrm{SC}\end{array}$ & 1.0 & 31.4 & 24.0 & 33.9 \\
\hline 6 & \multirow{4}{*}{ stalking } & $\begin{array}{l}\text { tebuconazole } 250 \mathrm{~g} / \mathrm{l}, \mathrm{EC} \\
\text { (standard) }\end{array}$ & 1.0 & 14.0 & 10.0 & 72.4 \\
\hline 7 & & $\begin{array}{l}\text { tebuconazole } 225 \mathrm{~g} / 1+ \\
\text { flutriafol } 75 \mathrm{~g} / 1, \mathrm{SC}\end{array}$ & 0.9 & 16.5 & 9.8 & 73.0 \\
\hline 8 & & $\begin{array}{l}\text { azoxystrobin } 200 \mathrm{~g} / 1+ \\
\text { cyproconazole } 80 \mathrm{~g} / 1, \mathrm{SC}\end{array}$ & 1.0 & 15.7 & 10.2 & 72.0 \\
\hline 9 & & $\begin{array}{l}\text { azoxystrobin } 120 \mathrm{~g} / 1+ \\
\text { tebuconazole } 200 \mathrm{~g} / 1, \mathrm{SC}\end{array}$ & 1.0 & 10.0 & 6.4 & 82.4 \\
\hline 10 & \multirow{4}{*}{ flowering } & $\begin{array}{l}\text { tebuconazole } 250 \mathrm{~g} / 1, \mathrm{EC} \\
\text { (standard) }\end{array}$ & 1.0 & 40.2 & 31.0 & 14.6 \\
\hline 11 & & $\begin{array}{l}\text { tebuconazole } 225 \mathrm{~g} / 1+ \\
\text { flutriafol } 75 \mathrm{~g} / \mathrm{l}, \mathrm{SC}\end{array}$ & 0.9 & 41.7 & 30.4 & 16.3 \\
\hline 12 & & $\begin{array}{l}\text { azoxystrobin } 200 \mathrm{~g} / 1+ \\
\text { cyproconazole } 80 \mathrm{~g} / 1, \mathrm{SC}\end{array}$ & 1.0 & 39.2 & 30.6 & 15.7 \\
\hline 13 & & $\begin{array}{l}\text { azoxystrobin } 120 \mathrm{~g} / 1+ \\
\text { tebuconazole } 200 \mathrm{~g} / 1, \mathrm{SC}\end{array}$ & 1.0 & 38.0 & 29.2 & 19.6 \\
\hline 14 & \multirow{3}{*}{ green pod } & $\begin{array}{l}\text { tebuconazole } 250 \mathrm{~g} / 1, \mathrm{EC} \\
\text { (standard) }\end{array}$ & 1.0 & 42.0 & 30.3 & 16.5 \\
\hline 15 & & $\begin{array}{l}\text { tebuconazole } 225 \mathrm{~g} / 1+ \\
\text { flutriafol } 75 \mathrm{~g} / 1, \mathrm{SC}\end{array}$ & 0.9 & 40.5 & 32.0 & 11.8 \\
\hline 16 & & azoxystrobin $200 \mathrm{~g} / 1+$ & 1.0 & 39.4 & 29.3 & 19.3 \\
\hline
\end{tabular}




\begin{tabular}{|l|l|l|l|l|l|l|}
\hline & & cyproconazole $80 \mathrm{~g} / \mathrm{l}, \mathrm{SC}$ & & & & \\
\cline { 1 - 6 } 17 & $\begin{array}{l}\text { azoxystrobin } 120 \mathrm{~g} / 1+ \\
\text { tebuconazole } 200 \mathrm{~g} / 1, \mathrm{SC}\end{array}$ & 1.0 & 40.3 & 30.8 & 15.2 \\
\hline
\end{tabular}

The treatment of brown mustard plants at the stage of 2-4 true leaves slightly decreased the prevalence and development of the disease (by 10.0-14.0 \% and 9.9-12.3\%, respectively). The biological effectiveness of all fungicides, including the standard, was low, amounting to $27.3-30.5 \%$.

We established that in the case of spraying of brown mustard plants at the stage of flowering and green pods, the prevalence and development of Fusarium blight was at the control level, amounting to 38.0-40.2 and 29.2-31.0\%, respectively, at the flowering stage, and 39.4-42.0 and 29.3-32.0\%, respectively, at the green pod stage.

The application of fungicides at a stage of stalking most effectively decreased the prevalence and development of the disease: by 29.0-35.5 and 26.1-29.9\%, respectively. We noted their maximum decrease in the variant № 9 (preparation with a.i. azoxystrobin 120 $\mathrm{g} / 1+$ tebuconazole $200 \mathrm{~g} / \mathrm{l} \mathrm{SC}$ ). The biological effectiveness of the fungicide in this variant was the highest $-82.4 \%$.

The counting of mustard seed yield showed the difference between the variants and the control, depending on the stage of preparations application (Table 5).

Table 5. Seed yield of brown mustard, 2018, 2020-2021.

\begin{tabular}{|c|c|c|c|c|c|c|}
\hline \multirow[b]{2}{*}{ № } & \multirow[b]{2}{*}{$\begin{array}{c}\text { Plant } \\
\text { developme } \\
\text { nt stage }\end{array}$} & \multirow[b]{2}{*}{$\begin{array}{c}\text { Variant } \\
\text { (a.i. of preparation) }\end{array}$} & \multirow[b]{2}{*}{$\begin{array}{l}\text { Applicat } \\
\text { i-on } \\
\text { rate, l/ha }\end{array}$} & \multicolumn{2}{|c|}{ Productivity } & \multirow[b]{2}{*}{$\underset{t \text {-test }}{\text { Actual }}$} \\
\hline & & & & t/ha & $\begin{array}{c} \pm \text { to the } \\
\text { control, } \\
\text { t/ha }\end{array}$ & \\
\hline 1 & & $\begin{array}{l}\text { Control (without } \\
\text { treatment) }\end{array}$ & - & 1.38 & - & - \\
\hline 2 & \multirow{4}{*}{$\begin{array}{l}2-4 \text { of true } \\
\text { leaves }\end{array}$} & $\begin{array}{l}\text { tebuconazole } 250 \mathrm{~g} / 1 \\
\text { (standard) EC }\end{array}$ & 1.0 & 1.46 & +0.08 & $\begin{array}{c}1.78< \\
\text { theor. }\end{array}$ \\
\hline 3 & & $\begin{array}{l}\text { tebuconazole } 225 \mathrm{~g} / 1+ \\
\text { flutriafol } 75 \mathrm{~g} / 1 \mathrm{SC}\end{array}$ & 0.9 & 1.50 & +0.12 & $\begin{array}{c}1.90< \\
t_{\text {theor. }}\end{array}$ \\
\hline 4 & & $\begin{array}{l}\text { azoxystrobin } 200 \mathrm{~g} / 1+ \\
\text { cyproconazole } 80 \mathrm{~g} / 1 \mathrm{SC}\end{array}$ & 1.0 & 1.49 & +0.11 & $\begin{array}{c}2.26< \\
t_{\text {theor. }}\end{array}$ \\
\hline 5 & & $\begin{array}{l}\text { azoxystrobin } 120 \mathrm{~g} / 1+ \\
\text { tebuconazole } 200 \mathrm{~g} / 1 \mathrm{SC}\end{array}$ & 1.0 & 1.50 & +0.12 & $\begin{array}{c}2.30< \\
\text { theor. }\end{array}$ \\
\hline 6 & \multirow{4}{*}{ stalking } & $\begin{array}{l}\text { tebuconazole } 250 \mathrm{~g} / 1 \\
\text { (standard) EC }\end{array}$ & 1.0 & 1.68 & +0.30 & $\begin{array}{c}3.36> \\
\text { theor. }\end{array}$ \\
\hline 7 & & $\begin{array}{l}\text { tebuconazole } 225 \mathrm{~g} / 1+ \\
\text { flutriafol } 75 \mathrm{~g} / 1 \mathrm{SC}\end{array}$ & 0.9 & 1.68 & +0.30 & $\begin{array}{c}3.40> \\
\text { theor. }\end{array}$ \\
\hline 8 & & $\begin{array}{l}\text { azoxystrobin } 200 \mathrm{~g} / 1+ \\
\text { cyproconazole } 80 \mathrm{~g} / 1 \mathrm{SC}\end{array}$ & 1.0 & 1.66 & +0.28 & $\begin{array}{c}3.20> \\
\text { theor. }\end{array}$ \\
\hline 9 & & $\begin{array}{l}\text { azoxystrobin } 120 \mathrm{~g} / 1+ \\
\text { tebuconazole } 200 \mathrm{~g} / 1 \mathrm{SC}\end{array}$ & 1.0 & 1.74 & +0.36 & $\begin{array}{c}3.88> \\
\text { theor. }\end{array}$ \\
\hline 10 & \multirow{4}{*}{ flowering } & $\begin{array}{l}\text { tebuconazole } 250 \mathrm{~g} / 1 \\
\text { (standard) EC }\end{array}$ & 1.0 & 1.49 & +0.11 & $\begin{array}{c}2.16< \\
\text { theor. }\end{array}$ \\
\hline 11 & & $\begin{array}{l}\text { tebuconazole } 225 \mathrm{~g} / 1+ \\
\text { flutriafol } 75 \mathrm{~g} / 1 \mathrm{SC}\end{array}$ & 0.9 & 1.48 & +0.10 & $\begin{array}{c}2.04< \\
t_{\text {theor. }}\end{array}$ \\
\hline 12 & & $\begin{array}{l}\text { azoxystrobin } 200 \mathrm{~g} / 1+ \\
\text { cyproconazole } 80 \mathrm{~g} / 1 \mathrm{SC}\end{array}$ & 1.0 & 1.46 & +0.08 & $\begin{array}{c}1.94< \\
t_{\text {theor. }}\end{array}$ \\
\hline 13 & & $\begin{array}{l}\text { azoxystrobin } 120 \mathrm{~g} / 1+ \\
\text { tebuconazole } 200 \mathrm{~g} / 1 \mathrm{SC}\end{array}$ & 1.0 & 1.50 & +0.12 & $\begin{array}{c}2.25< \\
\text { theor. }\end{array}$ \\
\hline 14 & \multirow[t]{2}{*}{ green pod } & $\begin{array}{l}\text { tebuconazole } 250 \mathrm{~g} / 1 \\
\text { (standard) EC }\end{array}$ & 1.0 & 1.43 & +0.05 & $\begin{array}{c}1.64< \\
t_{\text {theor. }}\end{array}$ \\
\hline 15 & & tebuconazole $225 \mathrm{~g} / 1+$ & 0.9 & 1.40 & +0.02 & $1.27<$ \\
\hline
\end{tabular}




\begin{tabular}{|c|c|l|c|c|c|c|}
\hline \multirow{2}{*}{16} & flutriafol $75 \mathrm{~g} / 1 \mathrm{SC}$ & & & & theor. \\
\cline { 3 - 6 } & $\begin{array}{l}\text { azoxystrobin } 200 \mathrm{~g} / \mathrm{l}+ \\
\text { cyproconazole } 80 \mathrm{~g} / 1 \mathrm{SC}\end{array}$ & 1.0 & 1.43 & +0.05 & $\begin{array}{c}1.80< \\
\mathrm{t}_{\text {theor. }}\end{array}$ \\
\cline { 3 - 7 } 17 & $\begin{array}{l}\text { azoxystrobin } 120 \mathrm{~g} / 1+ \\
\text { tebuconazole } 200 \mathrm{~g} / 1 \mathrm{SC}\end{array}$ & 1.0 & 1.44 & +0.06 & $\begin{array}{c}1.96< \\
\mathrm{t}_{\text {theor. }}\end{array}$ \\
\hline
\end{tabular}

${ }^{*} t_{\text {theor. }}=2.77$ at the significance level of 0.05 .

Seed yield in the variants №№ 6-9 on average for three years of research significantly exceeded the control - by $0.28-0.36 \mathrm{t} / \mathrm{ha}$. We observed the highest yield $(1.74 \mathrm{t} / \mathrm{ha})$ in the variant № 9 with the application of the preparation with a.i. azoxystrobin $120 \mathrm{~g} / 1+$ tebuconazole $200 \mathrm{~g} / \mathrm{l}, \mathrm{SC}$.

In all other variants, the seed yield of brown mustard did not significantly exceed the control or was at its level. The actual $t$-test in all variants is lower than the theoretical value.

\section{Discussion}

During the study of the effectiveness of a breeding method of protection of brown mustard sowings against Fusarium blight in the central zone of the Krasnodar region and as a result of the evaluation of mustard variety samples during four years of research, we selected material that will be used as a source of resistance to the disease in the breeding work for the development of new varieties.

The study of a chemical method of protection of brown mustard sowings against Fusarium blight has shown that treatment of plants with fungicides at the stages of 2-4 true leaves, flowering, and green pods did not decrease the prevalence and development of the disease. The biological effectiveness of the preparation was low, not exceeding $33.9 \%$.

We observed the lowest prevalence and development of Fusarium blight in the case of spraying of brown mustard with fungicides at the stalking stage. The best results showed the preparation with the active ingredients azoxystrobin $120 \mathrm{~g} / \mathrm{l}+$ tebuconazole $200 \mathrm{~g} / \mathrm{l}, \mathrm{SC}$ with the application rate of 1.0 1/ha: biological effectiveness in this variant was the highest $-82.4 \%$, the seed yield was significantly higher than control (by $0.36 \mathrm{t} / \mathrm{ha}$ ).

\section{Conclusion}

We selected the breeding material of brown mustard, resistant to Fusarium blight, exceeding the standard variety Yunona in yield by $0.20-0.26 \mathrm{t} / \mathrm{ha}$ and oil content by 2.0 $2.7 \%$. This material is advisable to use for developing new mustard varieties.

We determined the chemical fungicide with the active ingredients azoxystrobin $120 \mathrm{~g} / 1$ + tebuconazole $200 \mathrm{~g} / \mathrm{l}, \mathrm{SC}$ at the application rate of $1.0 \mathrm{l} / \mathrm{ha}$, which effectively decreases the prevalence and development of Fusarium blight on brown mustard when treating plants at the stalking stage. The biological effectiveness of the preparation was $82.4 \%$, the seed yield significantly exceeded the control (by $0.36 \mathrm{t} / \mathrm{ha}$ ). The treatment of brown mustard with this preparation will effectively preserve the seed yield with a sharp increase in the infestation of sowings with Fusarium blight.

Thus, to effectively reduce the harmfulness of Fusarium blight on brown mustard, it is recommended to use both breeding and chemical methods of sowings protection against the disease.

\section{References}

1. J. Chen, X. Bian, G. Rapp, J. Indust. Crops and Prod., 137 (2019) 
2. K. Das, M. Bhattacharya, M. Ghosh, J. Pharma Nutr., 14 (2020)

3. M. Rahman, A. Khatun, L. Liu, B.J. Barkla, J. Molecules, 23, 1 (2018)

4. S. Ravi, A. Karthikeyan, R.N. Kumar, E. Balaji, J. Materialstoday, 27 (2020)

5. R. Szőllösi, Nuts and Seeds in Health and Disease Prevention (Second Edition, 2020)

6. M. Fontana, L. Bragazza, T. Guillaume, M. Santonja, A. Buttler, S. Elfouki, S. Sinaj, J. of Environmental Manag., 285 (2021)

7. H. Friberg, V. Edel-Hermann, C. Faivre, N. Gautheron, L. Fayolle, J. Soil. Biol. and Biochem, 41, 10 (2009)

8. M. Divakaran, K.N. Babu, Encyclopedia of Food and Health (Elsevier, 2016)

9. S. Nehra, R.K. Gothwal, A.K. Varshney, P.S. Solanki, S. Chandra, P. Meena, J. Microbiome Stimulants for Crops. Mechanisms and Applications (2021)

10. O.A. Serdyuk, V.S. Trubina, L.A. Gorlova, BIO Web Conf. XI International Sci. and Pract. Conf. Bio. Plant Protection is the Basis of Agroecosystems Stabilization, (Krasnodar, 2020) 